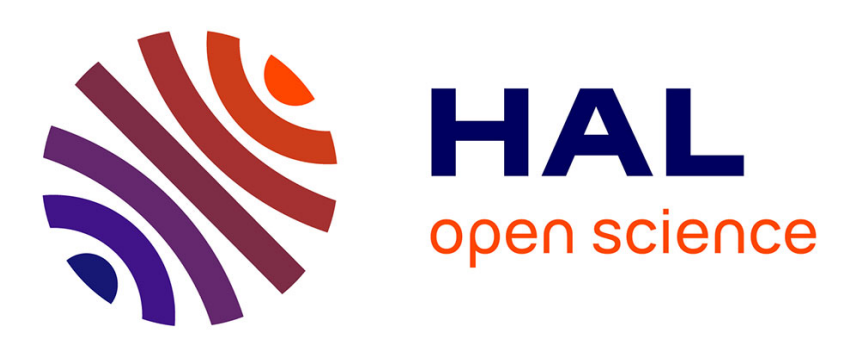

\title{
Are all species of Pseudorhabdosynochus strictly host specific? - a molecular study
}

Charlotte Schoelinck, Corinne Cruaud, Jean-Lou Justine

\section{To cite this version:}

Charlotte Schoelinck, Corinne Cruaud, Jean-Lou Justine. Are all species of Pseudorhabdosynochus strictly host specific? - a molecular study. Parasitology International, 2012, 61, 10.1016/j.parint.2012.01.009. 10.1016/j.parint.2012.01.009 . mnhn-00673113

\section{HAL Id: mnhn-00673113}

\section{https://hal-mnhn.archives-ouvertes.fr/mnhn-00673113}

Submitted on 22 Feb 2012

HAL is a multi-disciplinary open access archive for the deposit and dissemination of scientific research documents, whether they are published or not. The documents may come from teaching and research institutions in France or abroad, or from public or private research centers.
L'archive ouverte pluridisciplinaire HAL, est destinée au dépôt et à la diffusion de documents scientifiques de niveau recherche, publiés ou non, émanant des établissements d'enseignement et de recherche français ou étrangers, des laboratoires publics ou privés. 


\section{Are all species of Pseudorhabdosynochus strictly host specific? - a molecular study}

Charlotte Schoelinck (a, b) Corinne Cruaud (c), Jean-Lou Justine (a)

(a) UMR 7138 Systématique, Adaptation, Évolution, Muséum National d’Histoire Naturelle, Département Systématique et Évolution, CP 51, 55 Rue Buffon, 75231 Paris cedex 05, France.

(b) Service de Systématique moléculaire (CNRS-MNHN, UMS2700), Muséum National d'Histoire Naturelle, Département Systématique et Évolution, CP 26, 43 Rue Cuvier, 75231 Paris Cedex 05, France.

(c) Génoscope, Centre National de Séquençage, 2 rue Gaston Crémieux, CP 5706, 91057 Évry Cedex, France.

e-mails: $\quad$ CS : schoelinck@mnhn.fr

JLJ: justine@mnhn.fr

CC: cruaud@genoscope.cns.fr

Corresponding author:

Charlotte Schoelinck, Service de Systématique moléculaire, Muséum National d'Histoire Naturelle, Département Systématique et Évolution, CP 26, 43 Rue Cuvier, 75231 Paris Cedex 05, France, Telephone : +33 1407931 65, Fax : +3314079 3844 


\begin{abstract}
Species of the diplectanid monogenean genus Pseudorhabdosynochus are strictly host-specific (specialist), with the exception of $P$. cyanopodus, which was reported in New Caledonia, South Pacific, from two host species, Epinephelus cyanopodus and E. chlorostigma. We sequenced the COI gene of both host fish species and of their monogeneans. Morphological identification and pairwise distances showed that the two fish species were distinct (difference 6.1-6.6\%), but that their monogeneans were not (difference $0-1.5 \%$ ). A morphological study of sclerotised parts showed that specimens of $P$. cyanopodus are similar in both fish. Most species of groupers and their associated Pseudorhabdosynochus species are from warm surface waters, but the two groupers E. cyanopodus and E. chlorostigma are usually caught in deep-sea on the outer slope of the coral reef. This suggests that acquisition of a less strict host specificity is an adaptation of $P$. cyanopodus to deep-sea hosts.
\end{abstract}

\title{
1. Introduction
}

Species of the monogenean diplectanid genus Pseudorhabdosynochus are strictly host-specific. A study of more than 25 species of groupers [1] in the natural environment off New Caledonia, South Pacific, demonstrated that most grouper species harboured 1-8 species of Pseudorhabdosynochus, and that each of these monogenean species was "specialist", i.e. found on a single host species [1-9]. An exception was P. cyanopodus Sigura \& Justine, 2008, reported both from its type-host, Epinephelus cyanopodus, and from E. chlorostigma; however, this report was based only on comparative measurements [8]. In this paper, we provide additional morphological evidence and the first molecular confirmation of the presence of the same Pseudorhabdosynochus species on these two species of hosts, and we also confirm, with molecular methods, that the two host species are distinct.

\section{Material and Methods}

Fish were collected from off the barrier reef of New Caledonia $[5,8]$ or from the fish market of Nouméa, New Caledonia. Specimens of E. chlorostigma and E. cyanopodus were morphologically identified according to keys [10] and their identification was confirmed from photographs by confirmed ichthyologists. A photograph of specimen JNC3142 of E. chlorostigma was deposited in FishBase (www.fishbase.org). Parasites were collected [8] from 2 specimens of each fish species. Monogeneans were either processed for morphological examination [8] or for molecular characterization; in the latter case, each monogenean was examined with a microscope for species identification and then destroyed in the process of DNA extraction.

Fish DNA was extracted from tissue samples using NucleoSpin 96 tissue kit (MachereyNagel, Düren, Germany). Approximately 654 bp were amplified from the 5' region of the Cytochrome

Oxidase I (COI) gene from mitochondrial DNA using FishF1 (forward 5'- 
TCAACCAACCACAAAGACATTGGCAC-3') and FishR1 (Reverse 5'-TAGACTTCTGGGTGGCCAAAGAATCA3') [11]. Monogenean DNA was extracted from the whole specimen using DNeasy® 96 Blood \& Tissue kit (Qiagen). A fragment of $424 \mathrm{bp}$ of COI gene was amplified using the specific primers COI-ASmit1 (forward 5'-TTTTTTGGGCATCCTGAGGTTTAT-3') and COI-ASmit2 (reverse 5'-TAAAGAAAGAACATAATGAAAATG-3') [12]. Each PCR reaction was performed in final $20 \mu \mathrm{l}$ volume containing $1 \mathrm{ng}$ of DNA, $1 \times$ reaction buffer, $0.26 \mathrm{mM}$ dNTP, 0,8 $\mu \mathrm{M}$ of each primer, 5\% DMSO and 1.5 units of Taq DNA polymerase (Qiagen). Thermocycles consisted of an initial denaturation step at $94^{\circ} \mathrm{C}$ for 2', followed by 37 cycles of denaturation at $94^{\circ} \mathrm{C}$ for $30^{\prime \prime}$, annealing at $48^{\circ} \mathrm{C}$ for $40^{\prime \prime}$ and extension at $72^{\circ} \mathrm{C}$ for 1 '. The final extension was conducted at $72^{\circ} \mathrm{C}$ for $10^{\prime}$. Purification and cycle-sequencing reactions were performed at the Génoscope (Évry, France), using the BigDye Terminator version 3 sequencing kit, the GeneAmp PCR System 9700 and a capillary ABI3730 DNA Analyser, all from Applied Biosystems. Both DNA strands were sequenced for all PCR products. Sequences were edited and assembled using Sequencher 4.9 (Gene Codes Corporation, Ann Arbor, MI, USA). Sequences for this study were deposited as GenBank ID: JQ412500-JQ412503 (fish) and JQ400132-JQ400138 (monogeneans).

COI sequences were automatically aligned using ClustalW implemented in BioEdit version 7.0.5.3 [13]. The accuracy of automatic alignments was confirmed by eye. Uncorrected pairwise distances were computed using Mega 5 [14]. Results were visualized on a pairwise difference matrix. The identity of fish species was checked using BLAST in BOLD [15]; issues in the specific attribution of sequences are outlined below (3.1).

\section{Results}

\subsection{Analysis of fish COI sequences}

Sequences of our specimens of E. cyanopodus and E. chlorostigma showed low intraspecific variability (respectively $0.2 \%$ and $0.5 \%$ ), and high interspecific differences (6.1-6.6 \%) (Table 1). COI sequences are considered reliable indicators for species delimitation [11,16], and thus we consider that the two fish species were distinct. Sequences of E. cyanopodus from our specimens matched with the three deposited sequences of this species in BOLD with 99.84-100\% similarity (date: 11 January 2012; unpublished sequences in BOLD AMS513-08, EPINE003-11, EPINE003-12; no sequence in GenBank); we thus consider that molecular evidence confirms morphological identification. Sequences of our specimens of E. chlorostigma matched with the six deposited sequences of this species in GenBank with only 95.04-95.37\% (date: 11 January 2012; HQ149841 [17]; EF609514-5, EU39202-4 [18]). According to Heemstra \& Randall [10], two species, E. polylepis and E. gabriellae, were often misidentified as E. chlorostigma, but have different geographical distributions. On the basis of colour pattern and biogeographical distribution, we suggest that sequences previously deposited in GenBank as E. chlorostigma from the west coast of India [18] and the Persian Gulf [17] correspond to 
E. polylepis (this species ranges from the west coast of India to the Gulf of Aden [10]). We provisionally consider that our specimens correspond to E. chlorostigma (the species is already recorded from New Caledonia [10,19]) but we urge caution because the type locality of $E$. chlorostigma is the Seychelles in the Indian Ocean [10]; a molecular reappraisal of the status of $E$. chlorostigma and its close relatives is certainly needed, but is beyond the scope of this parasitological paper.

\subsection{Morphology of monogeneans}

Morphological examination of monogeneans (Fig. 1) demonstrated that the key structures which allow species differentiation [4,8,20], i.e. the sclerotised male copulatory organ (Fig. 1A, B) and vagina (Fig. 1C-E), were similar in P. cyanopodus from E. chlorostigma to the corresponding structures found in specimens from E. cyanopodus (see Figures 2-4 in [5]). The squamodiscs (Fig. 1J) showed "spurs", a structure not mentioned in the original description of P. cyanopodus [5], but this is not a reliable systematic character [8]. Measurements were similar (see Tables 2, 3 in [8]).

\subsection{Analysis of monogenean COI sequences}

Seven monogenean sequences were obtained. The difference matrix of monogenean COI sequences (Table 2) showed that variability ranged $0-0.5 \%$ for specimens from E. cyanopodus and 0.7-1.5\% for specimens from E. chlorostigma. Variability between monogeneans from the two fish species did not exceed $1.5 \%$. We consider that such small variability demonstrates that monogenean specimens from both fish species belong to a single species [21-23].

\section{Discussion}

Host specificity is one of the basic problems of parasitology. Euzet \& Combes [24] discussed the problem of species in parasites and remarked that most monogeneans are strictly host-specific ("oioxenous specificity") but rejected the description of new species of parasites on the simple basis of their recovery from a new species of host. Several genera of monopisthocotylean monogeneans include many species: these include the gyrodactylid Gyrodactylus [25], the dactylogyrids Anacanthorus [26] and Dactylogyrus [27], the ancyrocephalids Haliotrema [28,29], Haliotrematoides [30] and Ligophorus [31], and the diplectanids Lamellodiscus [23,32-34] and Pseudorhabdosynochus [1-9,20,35-38]. Strict or non-strict host specificity does not follow a regular pattern within genera; if we limit examples to diplectanids, species of Calydiscoides [39-41] and Lamellodiscus [23,32-34] show either strict specificity or are found in a small number of host species, but species of Pseudorhabdosynochus have hitherto been considered strictly host-specific, or "specialists" [1-9]. Reports of species of Pseudorhabdosynochus found in two fish species were considered erroneous and attributed to insufficient morphological differentiation [20,42] or to the fact that living fish of different species were kept together in a tank, thus allowing accidental host changes [20]. In wild conditions in 
New Caledonia, most species of Pseudorhabdosynochus have been found on a single host species only. The only exceptions are very small numbers of $P$. duitoe and $P$. huitoe $[5,8]$, and $P$. podocyanus, and the subject of the present study, P. cyanopodus.

The present study is the first molecular and morphological demonstration of infection of two species of naturally infected hosts, E. cyanopodus and E. chlorostigma, with the same species of Pseudorhabdosynochus. Our morphological [8] and molecular (unpublished COI sequences) studies of the other species of Pseudorhabdosynochus found on the same hosts show that they are distinct (no molecular data for $P$. podocyanus, which is rare).

The question is thus what conditions led to this exception? Our study of COI genes showed that the two fish species are distinct, confirming an earlier phylogeny based on other genes [43]. Although the depth recorded for both species is variable (4-300 $\mathrm{m}$ for E. chlorostigma, 2-150 m for E. cyanopodus [10,19]), in New Caledonian waters adults of both species are deep-sea fish, usually caught off the barrier reef at depths of 60-200 m. Parasite diversity is known to be much smaller in the deep sea than in surface waters [44-47], especially in comparison to such high diversity spots as coral reefs $[1,48]$, where most groupers live and from where most Pseudorhabdosynochus species have been described. In Dactylogyrus species from cyprinids in Europe, it has been demonstrated [49] that certain duplication events gave rise to generalist species (i.e. generalist parasite species are sometimes more derived than specialist species [49]). If such a process also occurs in Pseudorhabdosynochus, we may hypothesize that the low specificity of $P$. cyanopodus is a secondary adaptation to deep-sea conditions, where hosts are rare and separated by wide areas, and that infesting two species of hosts helps perpetuating the parasite species. Interestingly, $P$. epinepheli, another species recorded from $E$. chlorostigma [20] has a single host in New Caledonia but apparently several hosts in other localities [20,50,51]; however, molecular evidence is unavailable for P. epinepheli. We do not know why this process did not affect the other diplectanids [5,8] from E. cyanopodus and E. chlorostigma, or those from other deep-sea groupers studied in the same locality [52,53], all of which appear to be strictly specific species.

\section{Acknowledgements}

The identification of the hosts was kindly confirmed (from photographs) by John E. Randall (Bishop Museum, Hawaii). Aude Sigura and Émilie Henry, students, participated in the parasitological survey. Claude Chauvet (UNC, New Caledonia) kindly provided fish. David Gibson (NHM, London) provided advice for the title. Rod Bray (NHM, London) kindly edited the English. Funded by ATM barcode (MNHN) and ATM Biodiversité actuelle et fossile (MNHN). 


\section{References}

[1] Justine J-L, Beveridge I, Boxshall GA, Bray RA, Moravec F, Trilles J-P, et al. An annotated list of parasites (Isopoda, Copepoda, Monogenea, Digenea, Cestoda and Nematoda) collected in groupers (Serranidae, Epinephelinae) in New Caledonia emphasizes parasite biodiversity in coral reef fish. Folia Parasitol 2010; 57:237-62.

[2] Justine J-L. Species of Pseudorhabdosynochus Yamaguti, 1958 (Monogenea: Diplectanidae) from Epinephelus fasciatus and E. merra (Perciformes: Serranidae) off New Caledonia and other parts of the Indo-Pacific Ocean, with a comparison of measurements of specimens prepared using different methods, and a description of P. caledonicus n. sp. Syst Parasitol 2005; 62:1-37.

[3] Justine J-L. Pseudorhabdosynochus argus n. sp. (Monogenea: Diplectanidae) from Cephalopholis argus, $P$. minutus n. sp. and Diplectanum nanus n. sp. from C. sonnerati and other monogeneans from Cephalopholis spp. (Perciformes: Serranidae) off Australia and New Caledonia. Syst Parasitol 2007; 68:195-215.

[4] Justine J-L. Parasite biodiversity in a coral reef fish: twelve species of monogeneans on the gills of the grouper Epinephelus maculatus (Perciformes: Serranidae) off New Caledonia, with a description of eight new species of Pseudorhabdosynochus (Monogenea: Diplectanidae). Syst Parasitol 2007; 66:81129.

[5] Sigura A, Justine J-L. Monogeneans of the speckled blue grouper, Epinephelus cyanopodus (Perciformes, Serranidae), from off New Caledonia, with a description of four new species of Pseudorhabdosynochus and one new species of Laticola (Monogenea: Diplectanidae), and evidence of monogenean faunal changes according to the size of fish. Zootaxa 2008; 1695:1-44.

[6] Justine J-L, Sigura A. Monogeneans of the malabar grouper Epinephelus malabaricus (Perciformes, Serranidae) off New Caledonia, with a description of six new species of Pseudorhabdosynochus (Monogenea: Diplectanidae). Zootaxa 2007; 1543:1-44.

[7] Hinsinger DD, Justine J-L. The 'Pseudorhabdosynochus cupatus group' (Monogenea: Diplectanidae) on Epinephelus fasciatus, E. howlandi, E. rivulatus and E. merra (Perciformes: Serranidae) off New Caledonia, with descriptions of Pseudorhabdosynochus cyathus n. sp. and P. calathus n. sp. Syst Parasitol 2006; 64:69-90.

[8] Justine J-L, Henry É. Monogeneans from Epinephelus chlorostigma (Val.) (Perciformes: Serranidae) off New Caledonia, with the description of three new species of diplectanids. Syst Parasitol 2010; 77:81105.

[9] Schoelinck C, Justine J-L. Four species of Pseudorhabdosynochus (Monogenea: Diplectanidae) from the camouflage grouper Epinephelus polyphekadion (Perciformes: Serranidae) off New Caledonia. Syst Parasitol 2011; 79:41-61.

[10] Heemstra PC, Randall JE. FAO Species Catalogue. Vol. 16. Groupers of the world (Family Serranidae, Subfamily Epinephelinae). An annotated and illustrated catalogue of the grouper, rockcod, hind, coral grouper and lyretail species known to date Rome: FAO; 1993.

[11] Ward RD, Zemlak TS, Innes BH, Last PR, Hebert PD. DNA barcoding Australia's fish species. Philos Trans R Soc Lond B Biol Sci 2005; 360:1847-57.

[12] Littlewood DTJ, Rohde K, Clough KA. Parasite speciation within or between host species? - Phylogenetic evidence from site-specific polystome monogeneans. Int J Parasitol 1997; 27:1289-97.

[13] Hall TA. BioEdit: a user-friendly biological sequence alignment editor and analysis program for Windows 95/98/NT. Nucleic Acids Symp Ser 1999; 41:95-8.

[14] Tamura K, Peterson D, Peterson N, Stecher G, Nei M, Kumar S. MEGA5: Molecular evolutionary genetics analysis using maximum likelihood, evolutionary distance, and maximum parsimony methods. Mol Biol Evol 2011; 28:2731-2739.

[15] Ratnasingham S, Hebert PDN. BOLD: The Barcode of Life Data System (www. barcodinglife. org). Mol Ecol Notes 2007; 7:355-64.

[16] Hebert PDN, Ratnasingham S, de Waard JR. Barcoding animal life: cytochrome c oxidase subunit 1 divergences among closely related species. Proceedings of the Royal Society of London Series B: Biological Sciences 2003; 270:S96-S9.

[17] Asgharian H, Sahafi HH, Ardalan AA, Shekarriz S, Elahi E. Cytochrome c oxidase subunit 1 barcode data of fish of the Nayband National Park in the Persian Gulf and analysis using meta-data flag several cryptic species. Molec Ecol Res 2011; 11:461-72.

[18] Lakra WS, Verma MS, Goswami M, Lal KK, Mohindra V, Punia P, et al. DNA barcoding Indian marine fishes. Molec Ecol Res 2011; 11:60-71.

[19] Fricke R, Kulbicki M, Wantiez L. Checklist of the fishes of New Caledonia, and their distribution in the Southwest Pacific Ocean (Pisces). Stuttg Beitr Natkd Ser A (Biol) 2011; 4:341-463. 
[20] Justine J-L. A redescription of Pseudorhabdosynochus epinepheli (Yamaguti, 1938), the type-species of Pseudorhabdosynochus Yamaguti, 1958 (Monogenea: Diplectanidae), and the description of P. satyui n. sp. from Epinephelus akaara off Japan. Syst Parasitol 2009; 72:27-55.

[21] Smith MA, Fisher BL, Hebert PDN. DNA barcoding for effective biodiversity assessment of a hyperdiverse arthropod group: the ants of Madagascar. Philos Trans R Soc Lond B Biol Sci 2005; 360:1825-34.

[22] Ward RD. DNA barcode divergence among species and genera of birds and fishes. Molec Ecol Res 2009; 9:1077-85.

[23] Poisot T, Verneau O, Desdevises Y. Morphological and molecular evolution are not linked in Lamellodiscus (Plathyhelminthes [sic], Monogenea). PLoS ONE 2011; 6:e26252.

[24] Euzet L, Combes C. Les problèmes de l'espèce chez les animaux parasites. In: Boquet C, Génermont J, Lamotte $M$, editors. Les problèmes de l'espèce dans le règne animal. Mémoires de la Société Zoologique de France; 1980, p. 239-85.

[25] Bakke TA, Harris PD, Cable J. Host specificity dynamics: observations on gyrodactylid monogeneans. Int J Parasitol 2002; 32:281-308.

[26] Kritsky DC, Boeger WA, van Every LR. Neotropical Monogenoidea. 17. Anacanthorus Mizelle and Price, 1965 (Dactylogyridae, Anacanthorinae) from characoid fishes of the central Amazon. J Helminthol Soc Wash 1992; 59:25-51.

[27] Simkova A, Desdevises Y, Gelnar M, Morand S. Co-existence of nine gill ectoparasites (Dactylogyrus: Monogenea) parasitising the roach (Rutilus rutilus L.): history and present ecology. Int J Parasitol 2000; 30:1077-88.

[28] Kritsky DC, Stephens F. Haliotrema abaddon n. sp. (Monogenoidea: Dactylogyridae) from the gills of wild and maricultured west australian dhufish Glaucosoma hebraicum (Teleostei: Glaucosomatidae) in Australia. J Parasitol 2001; 87:749-54.

[29] Lim LHS, Justine J-L. Haliotrema banana sp. n. (Monogenea: Ancyrocephalidae) from Bodianus perditio (Perciformes: Labridae) off New Caledonia. Folia Parasitol 2007; 54:203-7.

[30] Kritsky DC, Yang T, Sun Y. Dactylogyrids (Monogenoidea, Polyonchoinea) parasitizing the gills of snappers (Perciformes, Lutjanidae): Proposal of Haliotrematoides n. gen. and descriptions of new and previously described species from marine fishes of the Red Sea, the eastern and Indo-west Pacific Ocean, Gulf of Mexico and Caribbean Sea. Zootaxa 2009; 1970:1-51.

[31] Dmitrieva EV, Gerasev PI, Merella P, Pugachev ON. Redescription of Ligophorus mediterraneus Sarabeev, Balbuena \& Euzet, 2005 (Monogenea: Ancyrocephalidae) with some methodological notes. Syst Parasitol 2009; 73:95-105.

[32] Diamanka A, Neifar L, Pariselle A, Euzet L. Lamellodiscus (Monogenea: Diplectanidae) parasites of Dentex macrophthalmus (Teleostei: Sparidae) from the North Atlantic coast of Africa, with a redescription of $L$. dentexi Aljoshkina, 1984, and description of three new species. Folia Parasitol 2011; 58:17-26.

[33] Justine J-L, Briand MJ. Three new species, Lamellodiscus tubulicornis n. sp., L. magnicornis n. sp. and $L$. parvicornis n. sp. (Monogenea: Diplectanidae) from Gymnocranius spp. (Lethrinidae: Monotaxinae) off New Caledonia, with proposal of the new morphological group 'tubulicornis' within Lamellodiscus Johnston \& Tiegs, 1922. Syst Parasitol 2010; 75:159-79.

[34] Ogawa K, Egusa S. Three species of Lamellodiscus (Monogenea Diplectanidae) from gills of Japanese Black Sea Bream, Acanthopagrus schlegeli (Bleeker). Bull Jpn Soc Sci Fish 1978; 44:607-12.

[35] Neifar L, Euzet L. Five new species of Pseudorhabdosynochus (Monogenea: Diplectanidae) from the gills of Epinephelus costae (Teleostei: Serranidae). Folia Parasitol 2007; 54:117-28.

[36] Mendoza-Franco EF, Violante-González J, Rojas Herrera AA. Six new and one previously described species of Pseudorhabdosynochus (Monogenoidea, Diplectanidae) infecting the gills of groupers (Perciformes, Serranidae) from the Pacific coasts of Mexico and Panama. J Parasitol 2011; 97:20-35.

[37] Schoelinck C, Justine J-L. Pseudorhabdosynochus quadratus n. sp. (Monogenea: Diplectanidae) from the white-streaked grouper Epinephelus ongus (Bloch) (Perciformes: Serranidae) off New Caledonia. Syst Parasitol 2011; 79:77-80.

[38] Sigura A, Chauvet C, Justine J-L. Pseudorhabdosynochus bacchus sp. nov. (Monogenea, Diplectanidae) from Epinephelus coeruleopunctatus (Perciformes, Serranidae) off New Caledonia. Acta Parasitol 2007; 52:196-200.

[39] Justine J-L. Species of Calydiscoides Young, 1969 (Monogenea: Diplectanidae) from lethrinid fishes, with the redescription of all of the type-specimens and the description of C. euzeti n. sp. from Lethrinus rubrioperculatus and L. xanthochilus off New Caledonia. Syst Parasitol 2007; 67:187-209.

[40] Justine J-L, Brena PF. Calydiscoides limae sp. nov. (Monogenea, Diplectanidae) from Pentapodus aureofasciatus (Perciformes, Nemipteridae) off New Caledonia. Acta Parasitol 2009; 54:22-7. 
[41] Rascalou G, Justine J-L. Three species of Calydiscoides (Monogenea: Diplectanidae) from five Lethrinus spp. (Lethrinidae: Perciformes) off New Caledonia, with a description of Calydiscoides terpsichore sp. n. Folia Parasitol 2007; 54:191-202.

[42] Justine J-L, Dupoux C, Cribb TH. Resolution of the discrepant host-specificity of Pseudorhabdosynochus species (Monogenea, Diplectanidae) from serranid fishes in the tropical Indo-Pacific. Acta Parasitol 2009; 54:119-30.

[43] Craig MT, Hastings PA. A molecular phylogeny of the groupers of the subfamily Epinephelinae (Serranidae) with a revised classification of the Epinephelini. Ichthyol Res 2007; 54:1-17.

[44] Rohde K. Gill Monogenea of deepwater and surface fish in southeastern Australia. Hydrobiologia 1988; 160:271-83.

[45] Klimpel S, Busch MW, Kellermans E, Kleinertz, Palm HW. Metazoan deep-sea fish parasites. Acta Biol Benrodis Supplbd 2009; 11:1-384.

[46] Bray RA, Littlewood DTJ, Herniou EA, Williams B, Henderson RE. Digenean parasites of deep-sea teleosts: a review and case studies of intrageneric phylogenies. Parasitology 1999; 119:S125-S44.

[47] Boxshall GA. Host specificity in copepod parasites of deep-sea fishes. J Mar Syst 1998; 15:215-23.

[48] Justine J-L. Parasites of coral reef fish: how much do we know? With a bibliography of fish parasites in New Caledonia. Belg J Zool 2010; 140 (Suppl.):155-90.

[49] Šimková A, Morand S, Jobet E, Gelnar M, Verneau O. Molecular phylogeny of congeneric monogenean parasites (Dactylogyrus): a case of intrahost speciation. Evolution 2004; 58:1001-18.

[50] Isshiki T, Nagano T, Miki K. Occurrence of a monogenean gill parasite Pseudorhabdosynochus epinepheli on red spotted grouper Epinephelus akaara and its experimental treatment by hydrogen peroxide bathing. Fish Pathol 2007; 42:71-4.

[51] Yamaguti S. Studies on the helminth fauna of Japan. Part 53. Trematodes of fishes, XII. Publ Seto Mar Biol Lab 1958; 7:53-88.

[52] Justine J-L. Two new species of Pseudorhabdosynochus Yamaguti, 1958 (Monogenea: Diplectanidae) from the deep-sea grouper Epinephelus morrhua (Val.) (Perciformes: Serranidae) off New Caledonia. Syst Parasitol 2008; 71:145-58.

[53] Justine J-L. Pseudorhabdosynochus inversus sp. nov. (Monogenea, Diplectanidae) from the halfmoon grouper Epinephelus rivulatus (Perciformes, Serranidae) off New Caledonia. Acta Parasitol 2008; 53:339-43. 


\section{Tables}

Table 1. Difference matrix of uncorrected pairwise differences between COI sequences of specimens of the two fish species E. cyanopodus and E. chlorostigma (two specimens per species). JNC numbers refer to individual fish identification.

\begin{tabular}{lllll}
\hline \multicolumn{1}{c}{ Fish species and specimen } & Sequence & [1] & [2] & [3] \\
\hline E. chlorostigma JNC3141 [1] & JQ412501 & & & \\
E. chlorostigma JNC3142 [2] & JQ412500 & 0.005 & & \\
E. cyanopodus JNC3262 [3] & JQ412503 & 0.066 & 0.063 & \\
E. cyanopodus JNC1625 [4] & JQ412502 & 0.065 & 0.061 & 0.002 \\
\hline
\end{tabular}

Table 2. Difference matrix of uncorrected pairwise differences between COI sequences of specimens of $P$. cyanopodus from two fish species. JNC numbers refer to individual fish identification.

\begin{tabular}{lcccccccc}
\hline Host fish species and specimen & $\begin{array}{c}\text { Monogenean } \\
\text { specimen }\end{array}$ & Sequence & [1] & [2] & [3] & [4] & [5] & [6] \\
\hline E. cyanopodus JNC3262 & {$[1]$} & JQ400132 & 0.000 & & & & \\
E. cyanopodus JNC3262 & {$[2]$} & JQ400133 & 0.000 & & & & \\
E. cyanopodus JNC3262 & {$[3]$} & JQ400134 & 0.000 & 0.000 & & & & \\
E. cyanopodus JNC3144 & {$[4]$} & JQ400137 & 0.005 & 0.005 & 0.005 & & \\
E. chlorostigma JNC3141 & {$[5]$} & JQ400135 & 0.007 & 0.007 & 0.007 & 0.002 & \\
E. chlorostigma JNC3141 & {$[6]$} & JQ400136 & 0.015 & 0.015 & 0.015 & 0.010 & 0.012 & \\
E. chlorostigma JNC3142 & {$[7]$} & JQ400138 & 0.009 & 0.010 & 0.009 & 0.005 & 0.007 & 0.015 \\
& & & & & & & \\
\hline
\end{tabular}

\section{Figure Legends}

Fig. 1. Pseudorhabdosynochus cyanopodus Sigura \& Justine, 2008 from Epinephelus chlorostigma. A, $\mathrm{B}$, quadriloculate male copulatory organ; $\mathrm{C}-\mathrm{D}$, sclerotised vagina; $\mathrm{F}-\mathrm{I}$, haptoral hard parts (F, lateral bar; G, ventral hamulus; $\mathrm{H}$, dorsal hamulus; I, ventral bar); J, dorsal squamodisc (dorsal view). J, carmine; A, C, D, F-I, picrate; B, D, Berlese. 


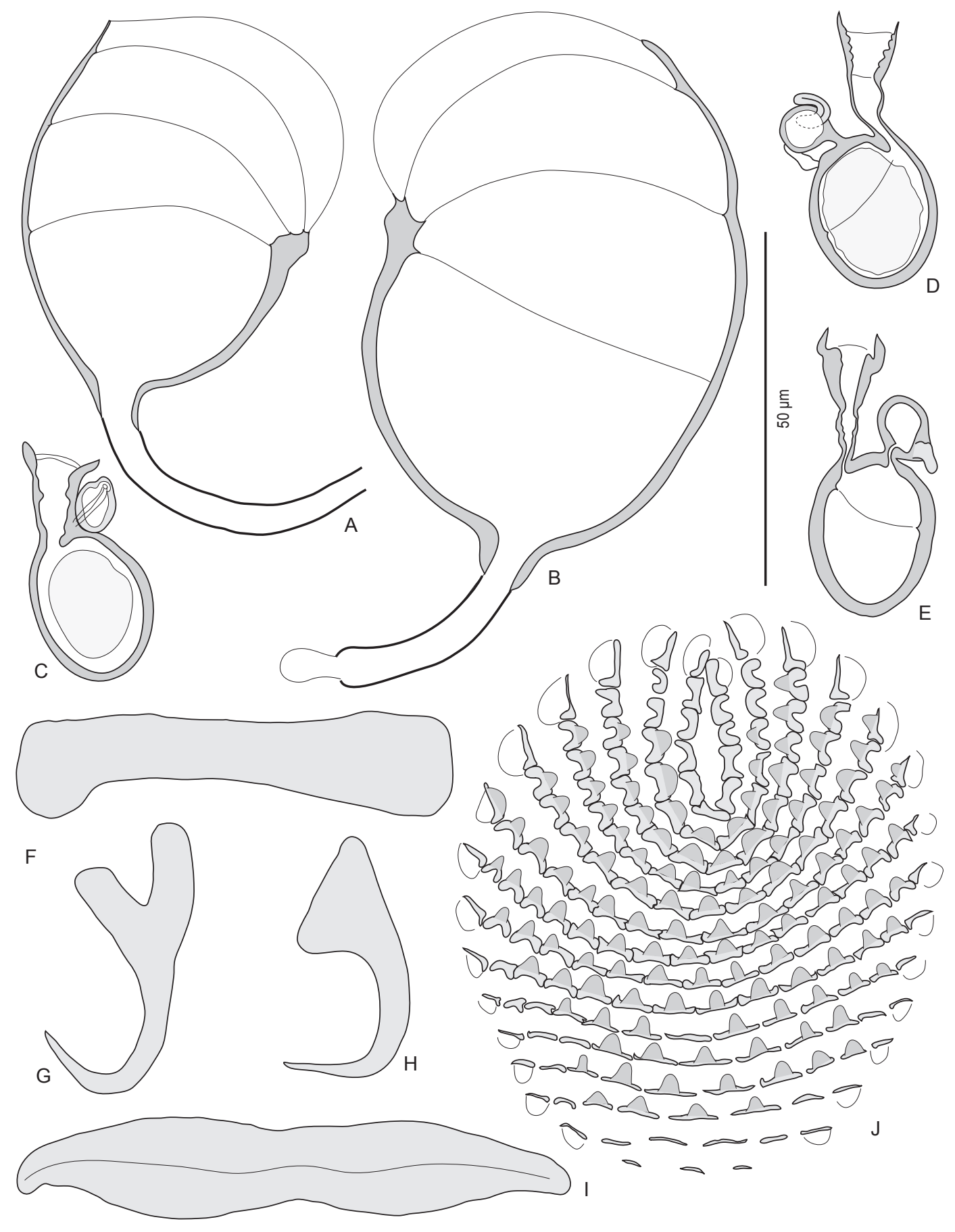

